\title{
A New Name for the Hawaiian Antipatharian Coral Formerly Known as Antipathes dichotoma (Cnidaria: Anthozoa: Antipatharia) ${ }^{1}$
}

\author{
Dennis M. Opresko
}

\begin{abstract}
A Hawaiian species of antipatharian coral previously identified as Antipathes dichotoma Pallas, 1766, is described as Antipathes griggi Opresko, n. sp. The species forms tall, bushy colonies with elongate, upright terminal branches, often arranged uniserially. Spines are conical, mostly 0.20 to 0.26 $\mathrm{mm}$ tall, apically bifurcated, multilobed to jagged in appearance, and covered over most of their surface with small roundish to elongate papillae. Minute secondary spines may occur on some of the thicker branches. Polyps are 1 to 1.6 $\mathrm{mm}$ in transverse diameter. The species resembles $A$. fruticosa Gray in branching pattern, size of spines, and presence of secondary spines but differs in morphology and density of the spines (thicker, more crowded primary spines and fewer secondary spines in A. griggi). Other related species differ from $A$. griggi in having more widely spreading and irregularly arranged branches, no secondary spines, and either smaller spines with fewer apical lobes (A. curvata van Pesch, $A$. arborea Dana, and $A$. galapagensis Deichmann) or larger spines with the apical lobes arranged in a somewhat coronate pattern [A. spinulosa (Schultze) and $A$. lentipinna Brook].
\end{abstract}

FOR MANY YEARS, a species of antipatharian coral common off the coasts of the Hawaiian Islands has been known as Antipathes dichotoma Pallas, 1766. Grigg and Opresko (1977) noted that the spines more closely resembled those of $A$. lentipinna Brook than those of $A$. dichotoma; however, at the time of publication of that report, specimens of the true $A$. dichotoma were not available for direct comparison. Based on the fact that van Pesch (1914) had synonymized $A$. lentipinna with $A$. dichotoma, the Hawaiian specimens were referred to $A$. dichotoma. A study of specimens of $A$. dicho-

\footnotetext{
${ }^{1}$ This work was supported in part by the National Museum of Natural History of the Smithsonian Institution, Washington, D.C., and by Oak Ridge National Laboratory, Oak Ridge, Tennessee. Collections by Pisces $I V / V$ were funded by a grant from the Western Pacific Fisheries Management Council. Manuscript accepted 16 April 2008.

${ }^{2}$ Environmental Sciences Division, Oak Ridge National Laboratory, 1060 Commerce Park, Oak Ridge, Tennessee 37830 (e-mail: dmopresko@hotmail.com).
}

Pacific Science (2009), vol. 63, no. 2:277-291

(C) 2009 by University of Hawai'i Press

All rights reserved toma from the Mediterrranean (the type locality), however, revealed that the Hawaiian species is quite distinct from the true $A$. dichotoma (see Opresko 2003). The Hawaiian species therefore requires the assignment of a new name. Although this species does show similarities to several other Pacific species $[A$. fruticosa Gray, 1857; A. curvata van Pesch, 1914; A. arborea Dana, 1846; A. galapagensis Deichmann, 1941; and A. spinulosa (Schultze, 1896)], there are sufficient differences to recognize it as a distinct species.

\section{MATERIALS AND METHODS}

The specimens on which this study is based were collected by a number of individuals, including R. Grigg, S. Kahng, T. Montgomery, C. Pittman, and H. Hall. The material was collected either by hand by scuba diving or by the use of the submersible Pisces $V$, operated by the Hawaiian Underseas Research Laboratory of the University of Hawai' $i$ and funded by a grant from the Western Pacific Fisheries Management Council. The microscopic skeletal features of the specimens were examined using a scanning electron microscope (Amray 1810) located at the 
U.S. National Museum of Natural History (NMNH, catalog numbers listed as USNM), Smithsonian Institution, Washington, D.C. The holotype and paratypes are deposited in the marine invertebrate collections of the NMNH. Schizoholotypes of related species were provided by the British Museum (вмNн), London; National Museum of Natural History (RMNH), Leiden, The Netherlands; Zoological Museum Amsterdam, University of Amsterdam (zMA), The Netherlands; and the Senckenberg Research Institute and Natural History Museum (smf), Frankfurt am Main, Germany.

RESULTS

Species Account

Family Antipathidae Ehrenberg, 1834 Genus Antipathes Pallas, 1766

Antipathes griggi Opresko, n. sp. Figures 1-4

not Antipathes dichotoma Pallas, 1766:216 (and later authors; see Brook [1889] and Opresko [2003] for synonymy).

Antipathes dichotoma, Grigg (1964, 1965, 2001, 2003, 2004); Grigg and Opresko (1977:242-261, fig. 9); Hoover (1998); Montgomery (2002); Boland and Parrish (2005); Fenner (2005); Kahng and Grigg (2005); Roark et al. (2006); Kahng and Kelley (2007).

Antipathes sp. Opresko (2003:491).

TYPE Material. Holotype (USNm 52436): Hawai'i, Maui, 150 ft (45.7 m), H. Hall, July 1961 (in alcohol). Paratypes (USNM 1111742): Hawai'i, Maui, 150 ft (45.7 m), H. Hall, July 1961 (several branches in alcohol; same lot as that of the holotype and most likely from the same colony). Paratype (USNM 1096156): Hawai'i, Maui, Circus Pinnacle, $20^{\circ}$ 52.928' $\mathrm{N}, 156^{\circ} 45.535^{\prime} \mathrm{W}$, Pisces $V$, dive $570,33 \mathrm{~m}$, S. Kahng, R Grigg, 11 September 2004 (one specimen, dry). Paratype (USNM 1099771): Hawai' $i$, off south coast of Kaua' $i, 21^{\circ} 51^{\prime}$ $18^{\prime \prime} \mathrm{N}, 159^{\circ} 26^{\prime} 11^{\prime \prime} \mathrm{W}, 51.8-54.9 \mathrm{~m}, \mathrm{~T}$. Montgomery, 5 April 2005 (one specimen, in alcohol). Paratype (usnm 1099770): Hawai'i, off south coast of Kaua'i, 21 $51^{\circ} 51^{\prime} 18^{\prime \prime} \mathrm{N}$, $159^{\circ} 26^{\prime} 11^{\prime \prime} \mathrm{W}, 51.8-54.9 \mathrm{~m}, \mathrm{~T}$. Montgomery, 5 April 2005 (one specimen, in alcohol).

ADDITIONAL MATERIAL EXAMINED. UsNm 1096165, Hawai'i, Kaua'i Island, $21^{\circ} 51.232^{\prime} \mathrm{N}, 159^{\circ} 26.218^{\prime} \mathrm{W}$, Pisces $V$, dive 573, 65 m, S. Kahng, R. Grigg, 14 September 2004 ( 1 specimen, dry). UsNM 1010711, Hawai'i, Maui Channel, $20^{\circ} 40^{\prime} \mathrm{N}, 156^{\circ} 42^{\prime} \mathrm{W}$, 50 m, R. Grigg, 1985 (1 specimen, dry). usNM 1096196, Hawai'i, south Kona, Kona Paradise Hotel area, $18 \mathrm{~m}$, S. Kahng, 14 February 2005 (1 specimen, dry). USNM 1096170, 1096175, 1096180, 1096184, 1096186, and 1096187: Hawai'i, 'Au'au Channel, 20 52.8' $\mathrm{N}, 156^{\circ} 45.8^{\prime} \mathrm{W}, 50 \pm 5 \mathrm{~m}$, Pisces $V$, R. Grigg, 15 May 2003 (6 specimens, dry). usNm 1096194, Hawai'i, Maui, 'Au'au Channel, probably 50-75 m, collected from rubble left on docks by black coral industry, C. Pittman (2 specimens, dry). UsNm 1096192: Hawai'i, Hawai'i Island, South Point, $40 \mathrm{~m}$, R. Grigg. usnm 1096162, Hawai'i, Ka'ula Island, southwest of Kaua'i Island, $21^{\circ} 41.305^{\prime}$ $\mathrm{N}, 160^{\circ} 36.289^{\prime} \mathrm{W}$, Pisces $V$, dive $571,60 \mathrm{~m}$, S. Kahng, 13 September 2004 (1 specimen, dry). USNM 1096195, Hawai'i, off south part of O'ahu Island, $20 \mathrm{~m}$, 19 January 2005, S. Kahng (1 specimen, in alcohol). USNM 1099769, Hawai'i, off south coast of Kaua'i, $21^{\circ} 51^{\prime} 18^{\prime \prime} \mathrm{N}, 159^{\circ} 26^{\prime} 11^{\prime \prime} \mathrm{W}, 51.8-54.9$ m, 5 April 2005, T. Montgomery (1 specimen, in alcohol).

Diagnosis. Colonies tall, up to $3 \mathrm{~m}$ or more, extensively branched with eight or more orders of branching. Branches long, distally directed, disposed irregularly on all sides of lower-order branches, but with highest order branchlets often arranged uniserially with five or more in a row. Terminal branchlets up to about $10 \mathrm{~cm}$ long without becoming subbranched. Distal branch angles generally $30^{\circ}$ to $45^{\circ}$.

Polypar spines on branchlets conical; acute to blunt; mostly 0.2 to $0.26 \mathrm{~mm}$ tall, but ranging from 0.16 to about $0.30 \mathrm{~mm}$; simple near tips of branchlets but becoming bifurcated, then multilobed and sometimes jagged in appearance farther away from distal end and on thicker branchlets; covered over most of 
surface with small roundish to elongate papillae. Abpolypar spines one-half to two-thirds the size of polypar spines. Small secondary spines, up to $0.04 \mathrm{~mm}$ tall, present on some branches. Primary spines arranged in axial rows; five to eight rows visible in lateral view on branchlets and smaller branches; rows becoming less distinct on larger branches with additional spines developing irregularly between rows. Spines in each row usually spaced 0.3 to $0.4 \mathrm{~mm}$ apart (range 0.2 to 0.6 $\mathrm{mm}$ ), with three to four (range two to six) spines per millimeter in each row.

Polyps typically 1.2 to $1.3 \mathrm{~mm}$ in transverse diameter (range 1 to $1.6 \mathrm{~mm}$ ); arranged in a single series on smallest branchlets, with six to nine (usually seven or eight) polyps per centimeter.

Color of living colonies red.

DESCRIPTION OF HOLOTYPE. The holotype is one of three clusters of branches in a single lot that presumably were handcollected from a single larger colony because the museum catalog indicates only one specimen for that USNM accession number. It is about $32 \mathrm{~cm}$ tall with a basal branch diameter of $3.5 \mathrm{~mm}$ (Figure $1 a$ ). Branching is irregular and somewhat bushy, although in places there is a tendency for subbranches to be arranged uniserially with three or four in a single row. Branches tend to be linear and elongate and extend vertically (or distally, relative to the lower-order branch from which they arise). A branch $17 \mathrm{~cm}$ long is about $1.3 \mathrm{~mm}$ in diameter at its basal end and has two subbranches. Branches are spaced various distances apart, from less than $1 \mathrm{~cm}$ to more than $5 \mathrm{~cm}$; usually there are no more than three branchlets per $5 \mathrm{~cm}$ length of branch. Distal branch angles are as narrow as $30^{\circ}$, but on thicker branches they may be up to about $45^{\circ}$. Terminal branchlets reach a maximum length of about $10 \mathrm{~cm}$ without subbranching. Thickness of the midpoint of the terminal branchlets is $0.3-0.4 \mathrm{~mm}$, excluding spines, and $0.5-0.6 \mathrm{~mm}$, including spines. A terminal branchlet $8 \mathrm{~cm}$ long is about 0.7 $\mathrm{mm}$ in basal diameter excluding spines, and about $1 \mathrm{~mm}$ in diameter including spines.

At the distal end of branchlets (diameter $0.1 \mathrm{~mm}$ ) the polypar spines are simple, laterally compressed, usually very acute, and curved distally. Farther away from the tip they become larger, more conical, and bifurcated or multilobed at the apex. Where the diameter of a branchlet is about $0.2 \mathrm{~mm}$, the polypar spines are up to $0.2 \mathrm{~mm}$ tall and a few are forked at the apex (Figures $2 a, 3 a$ ). Farther away from the distal end of a branchlet (diameter about $0.3 \mathrm{~mm}$ ) they are often bifurcate or trilobed (Figures $2 b, 3 b$ ). On branchlets $0.3-0.5 \mathrm{~mm}$ in diameter they are up to $0.25 \mathrm{~mm}$ tall and consistently multilobed (Figure 2c). Toward the basal part of a branchlet (diameter about $0.5-0.6 \mathrm{~mm}$ ) they become thick, blunt, and some have a jagged apex (Figures $2 d, 3 c$ ). Spines on branches are similar in size and morphology to those on lower parts of branchlets (Figures $2 e-f, 3 d$ ). A few small secondary spines can be found on branchlets as narrow as $0.4 \mathrm{~mm}$ in diameter (Figure 2c) but are more common on branches with a diameter of $1 \mathrm{~mm}$ or more. Secondary spines are up to $0.04 \mathrm{~mm}$ tall, laterally compressed, narrow, and acute. Up to four secondary spines can be found within an area of $0.01 \mathrm{~mm}^{2}$, but usually there are no more than two or three per $0.01 \mathrm{~mm}^{2}$.

The abpolypar spines are smaller than the polypar spines. Where polypar spines reach a maximum size of 0.2 to $0.24 \mathrm{~mm}$, abpolypar spines range from 0.1 to about $0.16 \mathrm{~mm}$. Polypar spines are usually inclined distally to a slight degree, although in some cases the distal edge may be almost at right angles to the surface of the axis. Abpolypar spines are also inclined distally. The surface of all the spines is covered with small, roundish to elongated papillae (elongated in the direction from apex to base of the spine). Papillae cover the surface of the spines from the tip to about four-fifths of the distance to the base (Figure $3 a-d)$. Near the tip of a branchlet four longitudinal rows of spines can be seen in one lateral view (excluding rows in which spines are only partially visible); on thicker parts of the branchlets there are up to eight rows of spines visible. Within each row, spines are 0.3-0.4 mm apart, resulting in three or four per millimeter. On larger branches arrangement of spines in rows becomes less distinct as a result of additional spines developing 


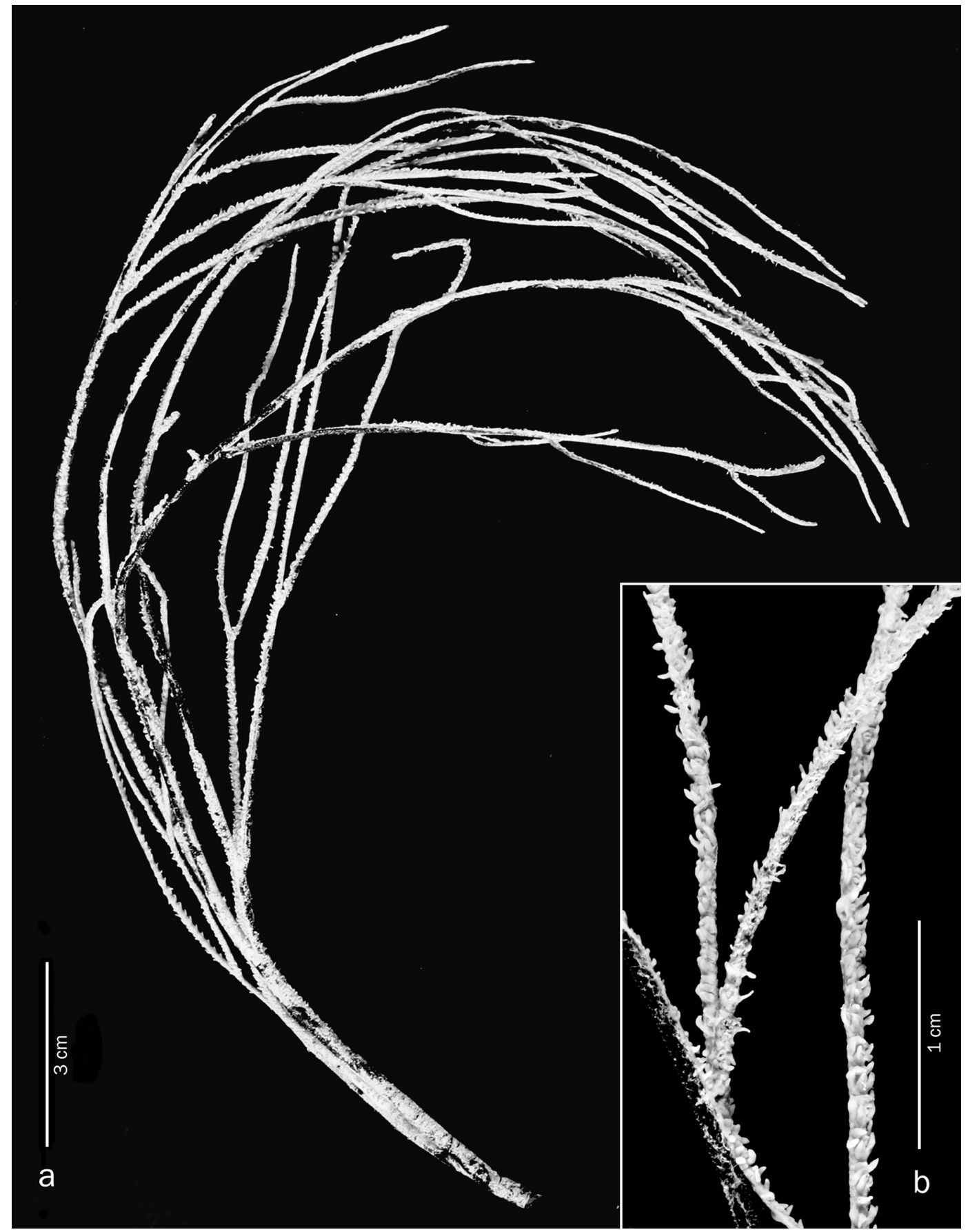

Figure 1. Antipathes griggi Opresko, n. sp., holotype (USNM 52436): $a$, one of three clusters of branches in the original accessioned lot; $b$, polyps on branchlets. 


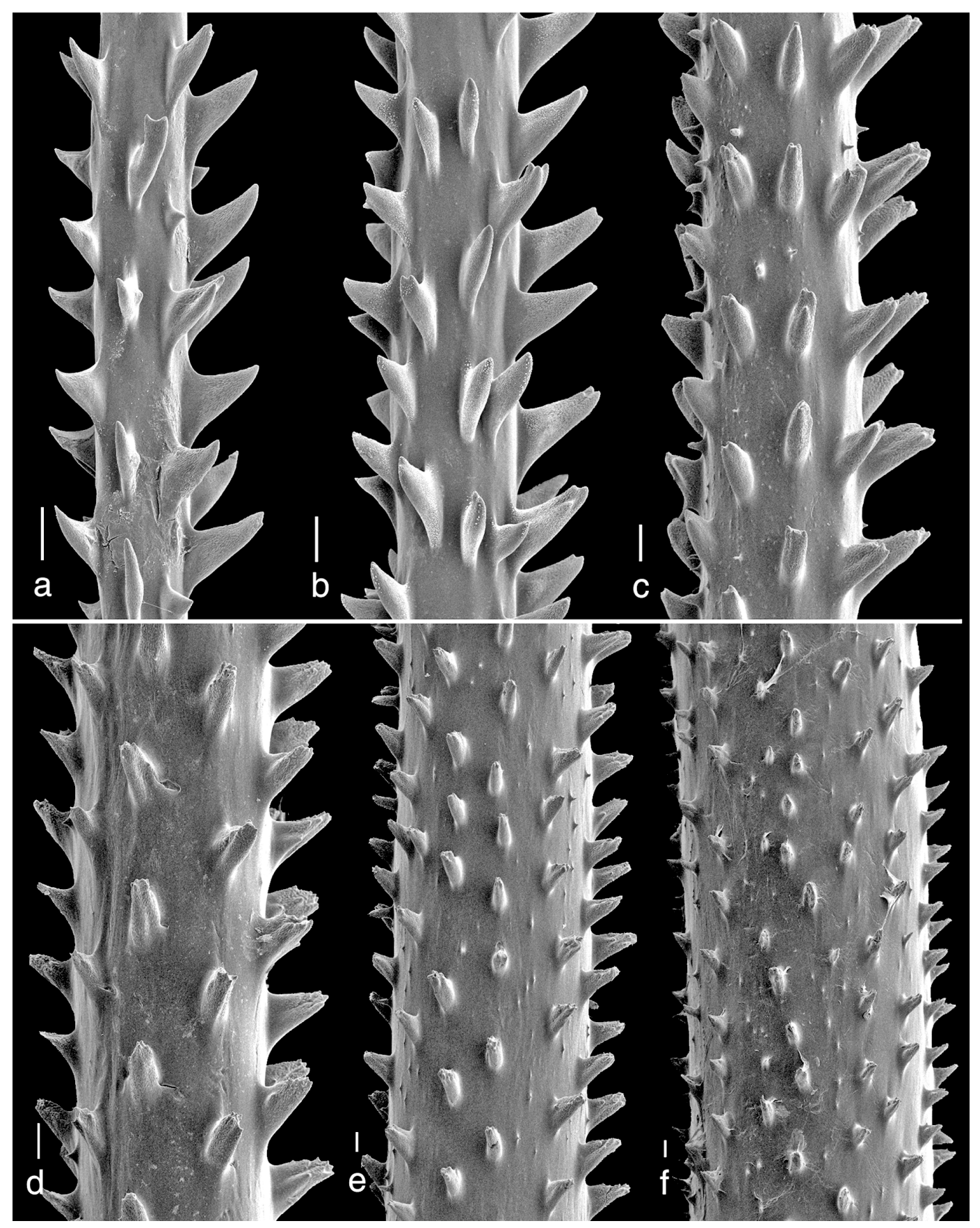

Figure 2. Antipathes griggi Opresko, n. sp., holotype (USNm 52436), spines on branchlets and branches: $a$, branch diameter $0.18 \mathrm{~mm} ; b, 0.27 \mathrm{~mm} ; c, 0.43 \mathrm{~mm} ; d, 0.56 \mathrm{~mm} ; e, 1 \mathrm{~mm} ; f, 1.5 \mathrm{~mm}$. Scale bars, $0.1 \mathrm{~mm}$. 


$$
\text { 弱 }
$$


in an irregular manner between rows. On a branch about $2 \mathrm{~mm}$ in diameter 12 or more rows can be seen in one lateral view. Spines on larger branches are 0.14 to $0.18 \mathrm{~mm}$ tall. In general, they are conical with coarser surface features than branchlet spines; however, they appear to have fewer bifurcations or are not as apically multilobed as those on branchlets.

Polyps are arranged in a single row on branchlets and smaller branches (Figure 1b). In the preserved state they measure 1.1 to $1.3 \mathrm{~mm}$ in transverse diameter (from distal side of base of distal lateral tentacles to proximal side of base of proximal lateral tentacles), and there are usually seven or eight polyps per centimeter. On larger branches (diameter of about $3 \mathrm{~mm}$ ) a few polyps may be found lateral to those arranged uniserially, indicating that on still larger branches polyps may occur in multiple rows. Color of living colonies is red.

INTRASPECIFIC VARIATION. In its typical form, colonies of $A$. griggi have terminal branches $0.5-0.6 \mathrm{~mm}$ in diameter (including spines), polypar spines $0.2-0.24 \mathrm{~mm}$ tall, and polyps that are, on average, about $1.2 \mathrm{~mm}$ in transverse diameter. In an examination of 16 specimens assigned to this species branchlet diameter (including spines) ranged from 0.4 to $1.0 \mathrm{~mm}$ (0.3-0.7 mm excluding spines); maximum size of polypar spines ranged from 0.16 to over $0.3 \mathrm{~mm}$; and maximum polyp size (transverse diameter) ranged from 1.0 $\mathrm{mm}$ to $1.6 \mathrm{~mm}$, with six to nine polyps per centimeter. Examples of the variability in the morphology and size of the spines from selected specimens are shown in Figure 4.

The range in variation in morphological characters can be correlated with several morphotypes that differ from the typical form in thickness of the terminal branchlets, and size and shape of the spines. In some specimens, terminal branchlets are thicker and polypar spines, on average, are larger than those in the typical form (sometimes exceeding 0.3 $\mathrm{mm}$ [see Figure $4 c]$ ). There are also specimens in which terminal branchlets are consistently thinner and spines smaller than the typical form (i.e., usually less than $0.2 \mathrm{~mm}$ ) and often with fewer apical notches or bifurcations (see Figure 4a). Secondary spines are present on some specimens (Figure 4e) but absent on others. Spines can be strongly laterally compressed (Figure $4 b$ ) or thick and blunt (Figure $4 d$ ). The degree to which tips of primary spines are lobed also varies from specimen to specimen. In many specimens apical lobes are limited to only two or three per spine and are very small; in other cases spines can become multilobed and jagged in appearance, as in the type. Substantial intraspecific variation in spine morphology and size is not unexpected for antipatharians (see Opresko 1996) and may be due to inherent or environmentally induced factors; however, at the same time closely related species may overlap in key taxonomic characters. In the latter case species differentiation may only be possible through careful field studies and DNA analyses.

Specimens provisionally identified as $A$. griggi collected from Ka'ula Island (USNM 1096162) are unique in several ways: (1) they have very thick terminal branchlets $(1-1.5$ $\mathrm{mm}$ with spines included); (2) branchlets have more rows of spines than the typical form; (3) polypar spines on terminal branchlets (Figure $4 f$ ) are very laterally compressed, extend out at right angles to the axis, and usually have only a small apical bifurcation; (4) multilobed spines occur only on lower parts of branchlets; and (5) polyps are relatively smaller than in the typical form, with eight or nine per centimeter. This morphotype has not been reported from any other location in the Hawaiian Islands (S. Kahng, pers. obs.), raising the possibility that it may be a genetically isolated population; however, the weight of evidence suggests that it may be a distinct species.

etymology. The name Antipathes griggi Opresko, n. sp., is given in recognition of the many years that Rick Grigg (professor emeritus at the University of Hawai' $i$ at Mānoa) has spent studying Hawaiian corals, and especially Hawaiian black corals.

distribution. Known only from the Hawaiian Islands at depths ranging from about 20 to $75 \mathrm{~m}$. 


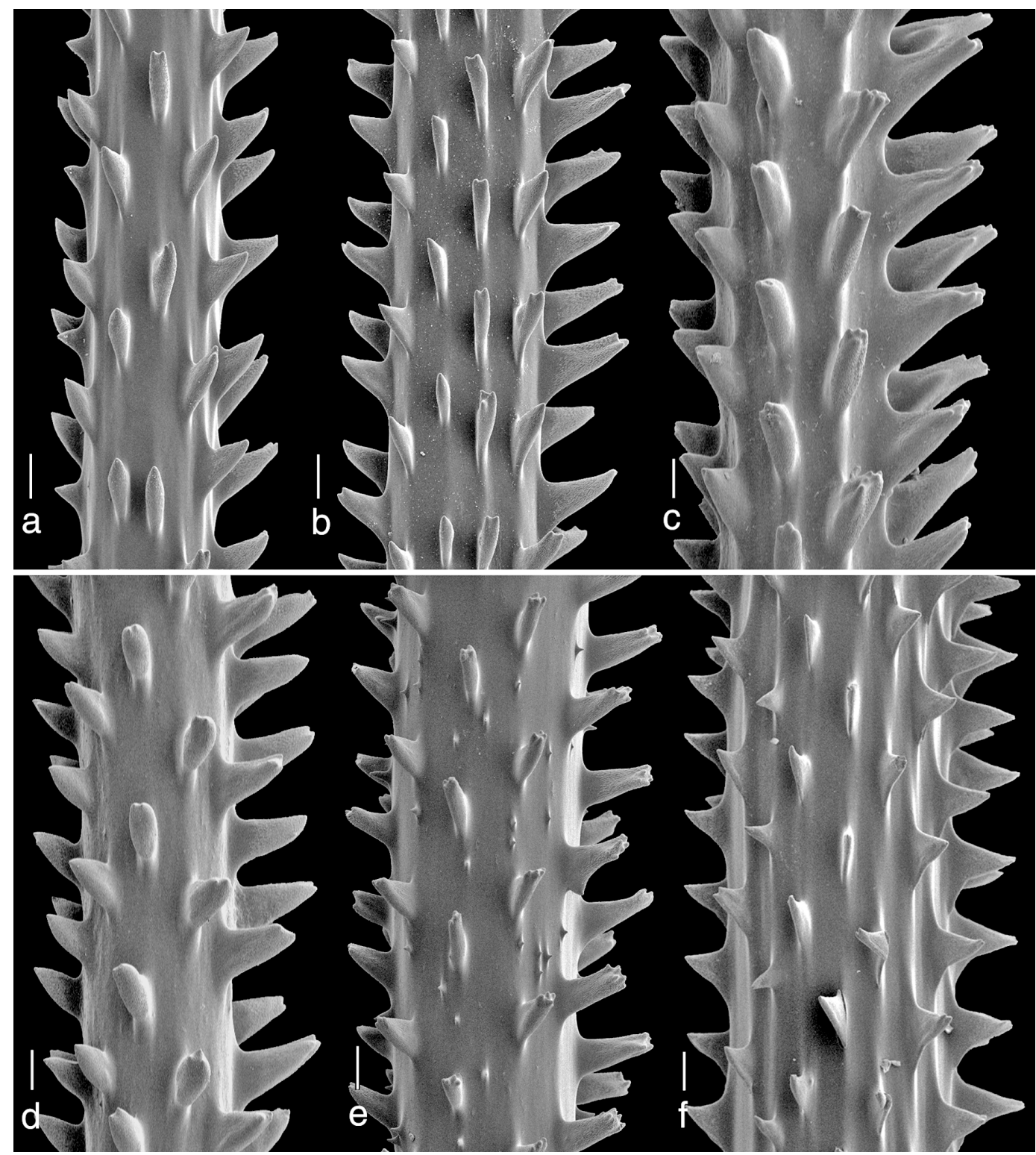

FIgURE 4. Antipathes griggi Opresko, n. sp. Spines on branchlets: $a$, USNM 1096165; $b$, USNM 1096156; $c$, USNM 1096187; $d$, USNM 1096175; $e$, USNM 1096196; $f$, USNM 1096162. Scale bars, $0.1 \mathrm{~mm}$.

\section{DISCUSSION}

As noted earlier, this species has for a long time been referred to Antipathes dichotoma Pallas, primarily because many species similar in external appearance to $A$. dichotoma had been synonymized by van Pesch (1914). A detailed evaluation of the limits of morphological variation of $A$. dichotoma (see Opresko 2003) resulted in the conclusion that the Hawaiian species is a different species.

Based on similarities in the morphology of 

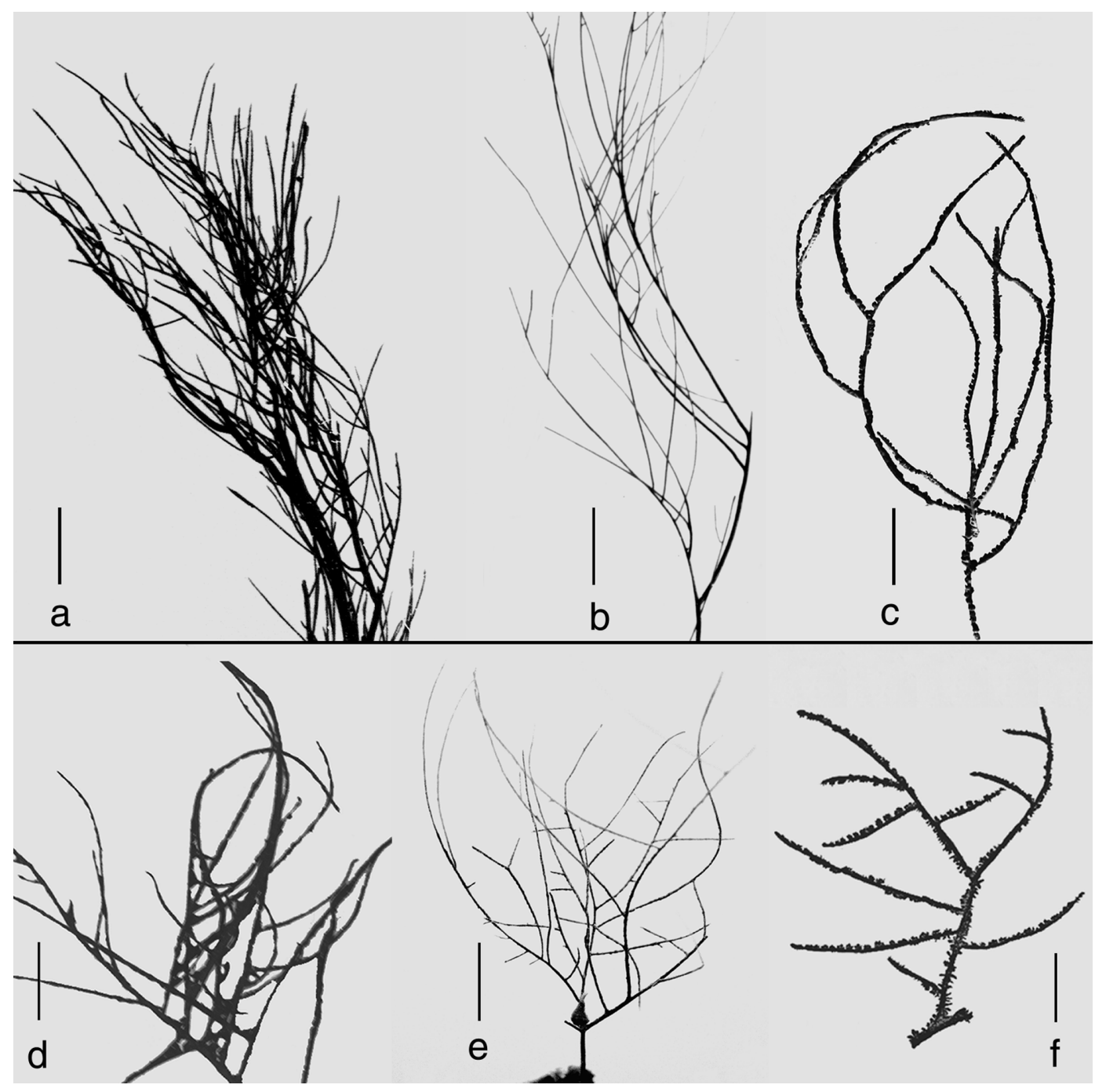

Figure 5. Comparison of branching patterns of species related to A. griggi: a, Antipathes fruticosa Gray, branch of holotype (вмNн 1846.8.3.130); b, A. lentipinna Brook, branch of type (вмNм 1973.9.20); $c$, A. galapagensis Deichmann, branch from holotype (usnm 43443); $d$, A. curvata van Pesch, part of holotype (zma Coel. 01793); e, A. spinulosa (Schultze), holotype (smF-93); $f$, $A$. arborea Dana, digital scan of illustration of branch of type specimen in Dana (1846). Scale bars, $2 \mathrm{~cm}$.

the corallum and spines, six nominal species appear to be related to $A$. griggi. These include Antipathes lentipinna Brook, 1889, from the Red Sea; $A$. curvata van Pesch, 1914, from Indonesia; $A$. arborea Dana, 1846, from Fiji; A. galapagensis Deichmann, 1941, from the Galápagos Islands; A. spinulosa (Schultze,
1896) from Indonesia; and A. fruticosa Gray, 1857, from New Zealand. These species resemble $A$. griggi in having a bushy, irregularly branched corallum (Figure 5) and spines with notches or multiple lobes at the apex (Figures 6 and 7). They are also alike in having various degrees of very fine sculpturing on the sur- 


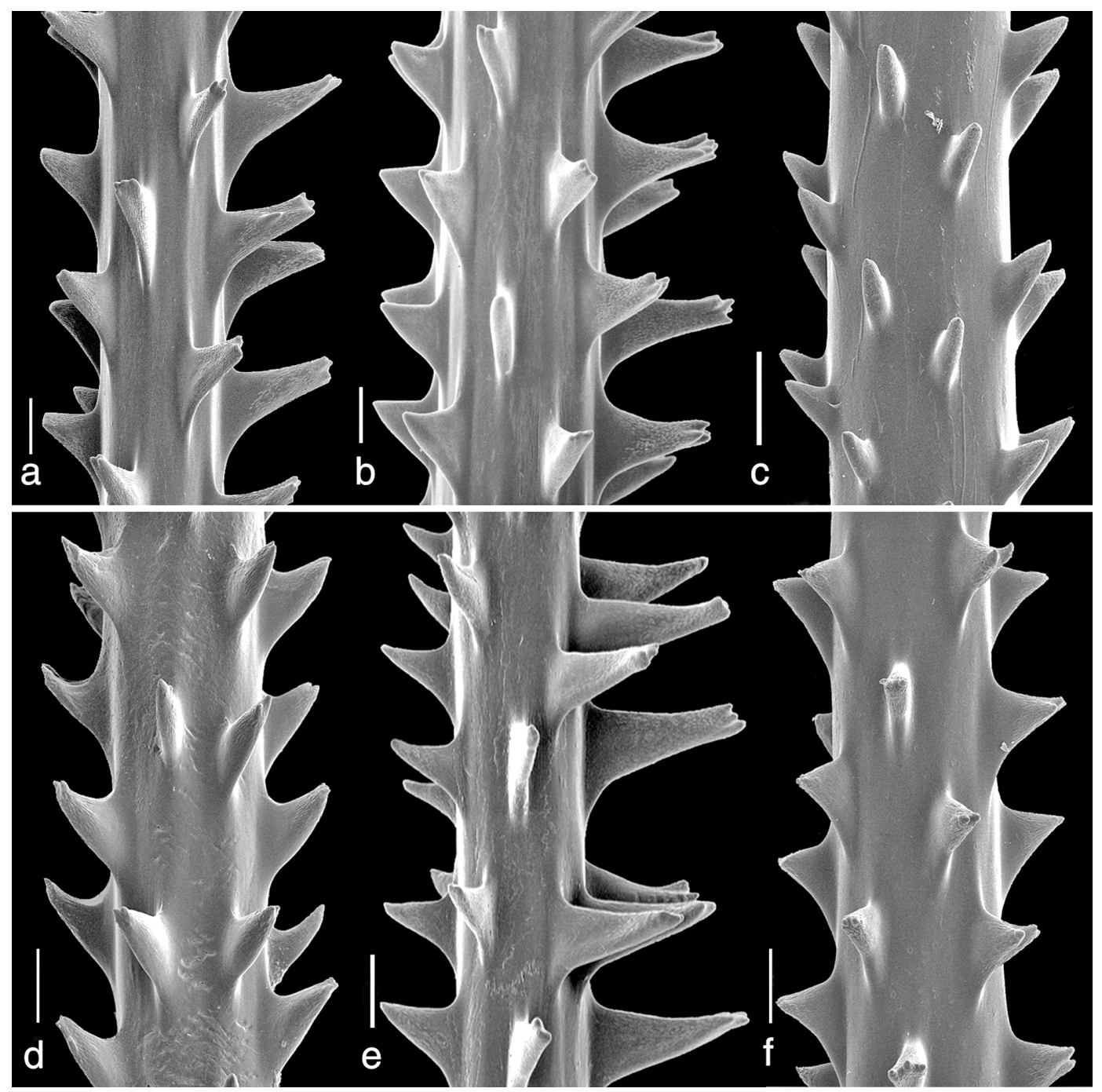

Figure 6. Comparison of skeletal spines of species related to A. griggi: a, Antipathes fruticosa Gray, schizoholotype (usnm 100398); $b$, A. lentipinna Brook, schizoholotype (usnm 100360); $c$, A. galapagensis Deichmann, holotype (usnm 43443); $d, A$. curvata van Pesch, schizoholotype (Usnm 100416); $e, A$. spinulosa (Schultze), holotype (smF-93); $f, A$. arborea Dana, holotype (мсz 54087). Scale bars, $0.1 \mathrm{~mm}$.

face of the spines that occur in the form of irregular, rounded, or elongated papillae or striations (Figure 7).

Grigg and Opresko (1977) had suggested that the Hawaiian species might be related to A. lentipinna Brook, 1889 , based on similarities in the morphology of the spines. An examination of the type specimen of $A$. lenti- pinna revealed that over most of the corallum the polypar spines are simple, or have only a few apical lobes, although on some branchlets they can have very distinct apical lobes arranged in a somewhat coronate pattern (Figures $6 b$ and $7 b$ ). This latter morphology is seen only rarely in $A$. griggi. In $A$. griggi the polypar spines can have a jagged appearance 

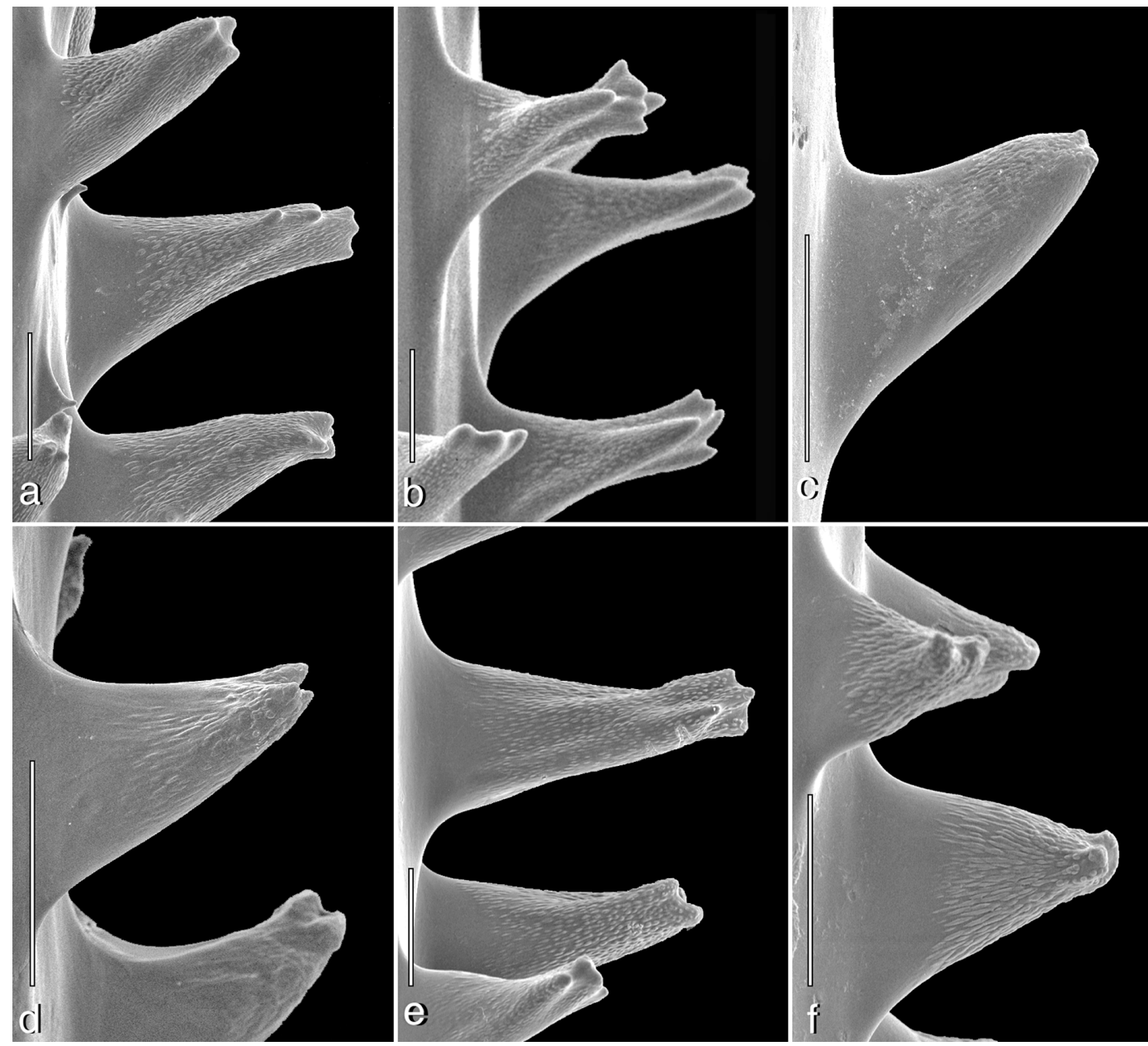

Figure 7. Comparison of single polypar spines of species related to A. griggi: a, Antipathes fruticosa Gray, schizoholotype (usnm 100398); $b$, A . lentipinna Brook, schizoholotype (UsNm 100360); $c$, A. galapagensis Deichmann, holotype (USNm 43443); $d$, A. curvata van Pesch, schizoholotype (USNm 100416); e, A. spinulosa (Schultze), holotype (smF-93); $f$, A. arborea Dana, holotype (Mcz 54087). Scale bars, $0.1 \mathrm{~mm}$.

(Figures $3 c-d$ ), a condition not seen in spines of A. lentipinna. Another difference between the two species is in the growth form of the corallum. The branching in $A$. griggi is more consistently vertically directed than that in $A$. lentipinna, although in parts of the corallum of the latter the branching is similar (Figure $5 b$ ). There also may be differences between the two species in the size of the polyps. Polyps were not present on the type of $A$. lentipinna; however, a specimen assigned to this species by Summers (1910) reportedly had polyps that were $2 \mathrm{~mm}$ in transverse diameter, larger than those in A. griggi (1-1.6 $\mathrm{mm})$. With the exception of $A$. fruticosa, polyps of the other species listed here are all within the size range of those of $A$. griggi. The polyps of $A$. fruticosa have not been described.

The species $A$. galapagensis, $A$. curvata, $A$. spinulosa, and $A$. arborea can be differentiated from $A$. griggi by corallum morphology in that they all have a more open type of branching pattern than $A$. griggi, with distal branch angles being as much as $90^{\circ}$ (Figure 


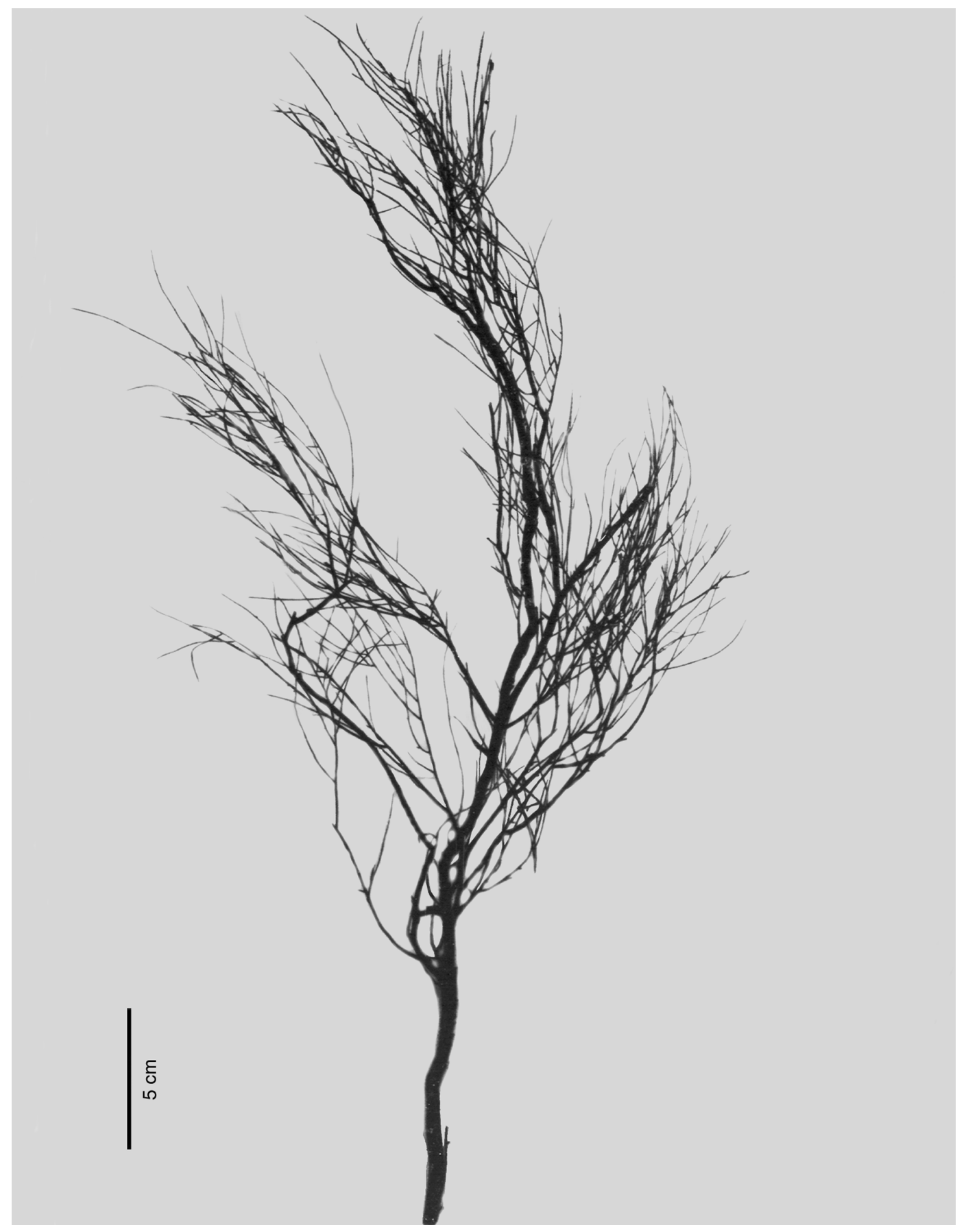

FIgURE 8. Antipathes fruticosa Gray, holotype (вмNн 1846.8.3.130). 


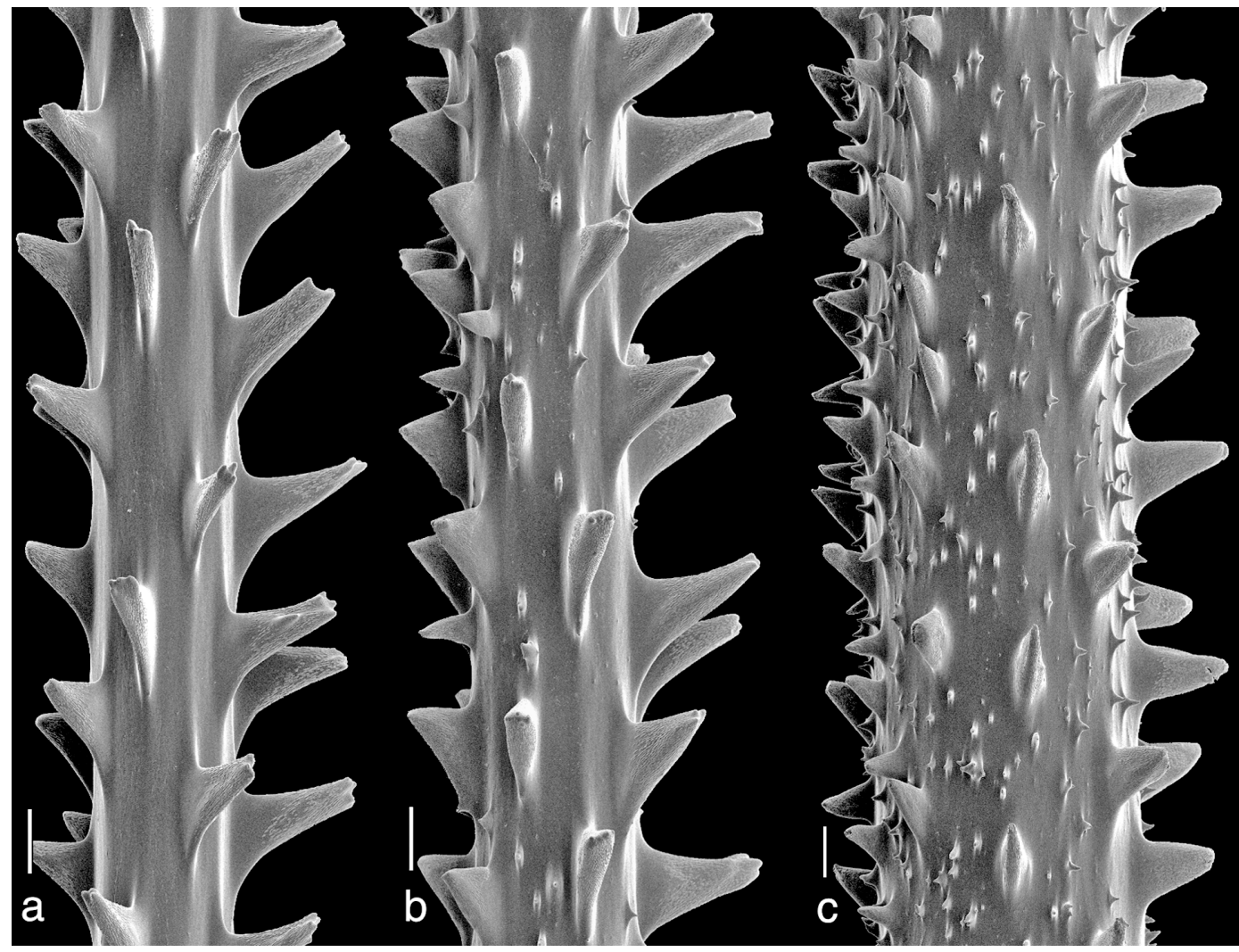

FIgURE 9. Antipathes fruticosa Gray, schizoholotype (USNM 100398): $a, 0.23 \mathrm{~mm}$ branchlet; $b, 0.26 \mathrm{~mm}$ branchlet; $c$, $0.53 \mathrm{~mm}$ branchlet. Scale bars, $0.1 \mathrm{~mm}$.

$5 c-f)$. They can also be differentiated from A. grigg $i$ by the size and morphology of their polypar spines. Polypar spines of $A$. galapagensis are conical, $0.14-0.16 \mathrm{~mm}$ tall, show only a slight indication of an apical bifurcation or notch (Figure $6 c$ ), and they have very irregular and faint surface sculpturing (Figure $7 c$ ). In the type of $A$. aborea, the polypar spines are triangular in lateral view, laterally compressed, no more than $0.15 \mathrm{~mm}$ tall, with small lobes at the apex (Figure $6 f$ ), and with elongated papillae on the upper half of their surface (Figure $7 f$ ). Polypar spines in the type of $A$. curvata are $0.12-0.18 \mathrm{~mm}$ tall, triangular on the smallest branchlets, but more conical and more inclined distally on the larger branchlets (Figure $6 d$ ). Some are bifurcated or multiply lobed at the apex, and they also have very small striations on the surface, but these tend to be confined to the upper half of the spine (Figure $7 d$ ). In $A$. spinulosa, the polypar spines (Figure $6 e$ ) are up to $0.34 \mathrm{~mm}$ tall, stand out at right angles to the axis, and have distinct apical lobes (Figure $7 e$ ) arranged in a coronate pattern similar to that seen in $A$. lentipinna. In some cases the apical lobes of the spines extend down the sides as much as halfway to the base. Small papillae cover much of the surface of the spines (Figure $7 e$ ). In $A$. griggi, the spines are typically $0.2-0.24 \mathrm{~mm}$ tall, range from being bilobed to multiply knobbed and even jagged at the apex, and have round to elongated papillae that cover the surface almost to the base. Overall, spines in $A$. griggi are larger than those in $A$. arborea, $A$. curvata, and $A$. galapagensis and smaller than those in $A$. spinulosa. It should be noted, however, that the 
thin-branched morphotype of $A$. griggi has spines that are uniformly smaller than those of the typical form and more similar to those of $A$. curvata, and the thick-branched morphotype has spines that approach those of $A$. spinulosa in size. Nevertheless, differences in the growth form of the corallum and the morphology of the spines, including the apical modifications and the fine surface sculpturing, argue against their belonging to these species.

The species most closely resembling $A$. grigg $i$ in both the appearance of the corallum and in the size of the spines is A. fruticosa from New Zealand. This species forms large, bushy colonies with terminal branchlets 3-10 cm long that are often arranged uniserially and directed upward (Figure 8), very much like the branching pattern in A. griggi. Polypar spines (Figure 9) are similar in size $(0.24$ $\mathrm{mm}$ ) and shape to those of $A$. griggi, and secondary spines are present on most branches. The species differ most noticeably in the size and density of the secondary spines. In $A$. fruticosa secondary spines are up to $0.05 \mathrm{~mm}$ tall, and there are four to five per $0.01 \mathrm{~mm}^{2}$. In contrast, in $A$. griggi secondary spines are generally less than $0.04 \mathrm{~mm}$, and there are usually only two to three per $0.01 \mathrm{~mm}^{2}$. Conversely, primary spines in $A$. fruticosa are not as crowded (about two per millimeter in each row) as those in $A$. griggi (three to four per millimeter in each row). There are also slight differences between the two species in the apical lobes of the primary spines. In $A$. fruticosa these tend to be more confined to the apex and, in places, have a more coronate arrangement as in $A$. lentipinna and $A$. spinulosa. In addition, in contrast to the case in $A$. griggi, apical lobes are more common on spines on the thinnest parts of the branchlets (Figure $9 a$ ) but less common on the thicker parts, where tips of the spines have a more blunt, rounded appearance (Figure 9c). Comparison of the polyps of the two species is not possible because the type specimen of $A$. fruticosa is a dry specimen without polyps.

\section{ACKNOWLEDGMENTS}

Specimens discussed in this paper were collected and made available through the efforts of R. Grigg, S. Kahng, T. Montgomery, D. Wagner, E. Chave, C. Pittman, and H. Hall, and their contribution to this study is gratefully acknowledged. I also wish to thank S. Cairns, T. Coffer, and W. Keel of the NMNH; B. W. Hoeksema, L. P. van Ofwegen, and M. Slierings of the Naturalis, Leiden; R. van Soest of the Zoological Museum Amsterdam; S. Halsey of the British $\mathrm{Mu}-$ seum; M. Grasshoff of the Senckenberg Institute; and A. Johnston of the Museum of Comparative Zoology for their assistance while I was visiting their respective museums and for making material available for study. The photomicrographs were prepared in the Scanning Electron Microscopy Laboratory of the NMNH, Smithsonian Institution. S. D. Whittaker of the NMNH kindly assisted in the SEM analysis. Special thanks are also extended to R. Baron-Szabo, T. Molodtsova, and S. Cairns for their careful reviews of the manuscript. I am a Research Associate of the $\mathrm{NMNH}$ and gratefully acknowledge that affiliation.

\section{Literature Cited}

Boland, R. C., and F. A. Parrish. 2005. A description of fish assemblages in the black coral beds off Lahaina, Maui, Hawai'i. Pac. Sci. 59:411-420.

Brook, G. 1889. Report on the Antipatharia. Rep. Sci. Res. Voy. H.M.S. Challenger, Zool. 32 (80): 1-222, pls 1-15.

Dana, J. D. 1846. Zoophytes. United States Exploring Expedition 7, vi $+740,+$ atlas of 61 pls.

Deichmann, E. 1941. Coelenterates collected on the presidential cruise of 1938. Smithson. Misc. Coll. 99 (10): 1-17, 1 pl.

Ehrenberg, C. G. 1834. Die Corallenthiere des rothen Meeres. K. Acad. Wiss. Berl. $1-156$.

Fenner, D. 2005. Corals of Hawai'i: A field guide to the hard, black, and soft corals of Hawai' $i$ and the Northwest Hawaiian Islands including Midway. Mutual Publishing, Honolulu.

Gray, J. E. 1857. Synopsis of the families and genera of axiferous zoophytes or barked corals. Proc. Zool. Soc. Lond. 25:278294, pl. 9. 
Grigg, R. W. 1964. A contribution to the biology and ecology of the black coral, Antipathes grandis in Hawaii. Department of Zoology, University of Hawai'i at Mānoa, Honolulu. 74 pp.

1965. Ecological studies of black coral in Hawaii. Pac. Sci. 19:244-260.

- 2001. Black coral: History of a sustainable fishery in Hawai'i. Pac. Sci. 55:291-299.

- 2003. Invasion of a deep-water black coral bed by an alien species Carijoa riisea. Maui, Hawaii. Coral Reefs 22:121-122.

- 2004. Harvesting impacts and invasion by an alien species decrease estimates of black coral yield off Maui, Hawai'i. Pac. Sci. 58:1-6.

Grigg, R., and D. M. Opresko. 1977. The Antipatharia. Pages 242-262 in C. Edmondson, ed. (rev. ed., D. Devaney and L. Eldredge, eds.), Reef and shore fauna of Hawaii. Bernice P. Bishop Mus. Spec. Publ. 64.

Hoover, J. P. 1998. Hawai'i's sea creatures. A guide to Hawai'i's marine invertebrates. Mutual Publishing, Honolulu.

Kahng, S. E., and R. Grigg. 2005. Impact of an alien octocoral, Carijoa riisei, on black corals in Hawaii. Coral Reefs 24:556-562.

Kahng, S. E., and C. Kelley. 2007. Vertical zonation of megabenthic taxa on a deep photosynthetic reef $(50-140 \mathrm{~m})$ in the 'Au'au Channel, Hawaii. Coral Reefs 26:679-687.

Montgomery, A. D. 2002. The feasibility of transplanting black coral (Order Antipatharia). Hydrobiologia 471:157-164.

Opresko, D. M. 1996. New species of black coral (Cnidaria: Antipatharia) from the Caribbean. Bull. Mar. Sci. 58:289-300.

. 2003. Redescription of Antipathes dichotoma Pallas, 1766 (Cnidaria: Anthozoa: Antipatharia). Zool. Meded. (Leiden) 77:481-493.

Pallas, P. S. 1766. Elenchus Zoophytorum Sistens Generum Adumbrationes Generaliores et Specierum Cognitarum Succinctas Descriptiones cum Selectis Auctorum Synonymis. Hagae-Comitum. xvi $+28+451$.

Roark, E. B., T. P. Guilderson, R. B. Dunbar, and L. Ingram. 2006. Radiocarbon-based ages and growth rates of Hawaiian deepsea corals. Mar. Ecol. Prog. Ser. 327:1-14.

Schultze, L. S. 1896. Beitrag zur Systematik der Antipatharien. Abh. Senckenb. Naturforsch. Ges. 23:1-40.

Summers, S. L. M. 1910. Antipatharia from the Indian Ocean. J. R. Microsc. Soc. (1910): 273-281, 1 pl.

van Pesch, A. J. 1914. The Antipatharia of the Siboga Expedition. Siboga Expeditie Monographie 17:1-258. 
